NBER WORKING PAPER SERIES

\title{
ABORTION LEGALIZATION AND ADOLESCENT SUBSTANCE USE
}

\author{
Kerwin Kofi Charles \\ Melvin Stephens Jr. \\ Working Paper 9193 \\ http://www.nber.org/papers/w9193 \\ NATIONAL BUREAU OF ECONOMIC RESEARCH \\ 1050 Massachusetts Avenue \\ Cambridge, MA 02138 \\ September 2002
}

\begin{abstract}
We have benefited from discussions with John Bound, John DiNardo, Doug Staiger, and David Thatcher. We are grateful to Arthdale Brown and Pawan Khera for research assistance. We would like to thank the Heinz School for financial support. The views expressed herein are those of the authors and not necessarily those of the National Bureau of Economic Research.

(C) 2002 by Kerwin Kofi Charles and Melvin Stephens Jr. All rights reserved. Short sections of text, not to exceed two paragraphs, may be quoted without explicit permission provided that full credit, including (C) notice, is given to the source.
\end{abstract}


Abortion Legalization and Adolescent Substance Use

Kerwin Kofi Charles and Melvin Stephens Jr.

NBER Working Paper No. 9193

September 2002

JEL No. I12, J13

\begin{abstract}
We assess whether in utero exposure to legalized abortion in the early 1970's affected individuals' propensities to use controlled substances as adolescents. We exploit the fact that some states legalized abortion before national legalization in 1973 to compare differences in substance use for adolescents across birth cohorts in different states. We find that persons exposed to early legalization were, on average, much less likely to use controlled substances. We also assess how substance use varies with state level birth rates and abortion ratios. Overall, our results suggest that legalization lowered substance use because of the selective use of abortion by relatively disadvantaged women.
\end{abstract}

Kerwin Kofi Charles

Department of Economics

and Ford School of Public Policy

University of Michigan

611 Tappan Street

Ann Arbor, MI 48109

and NBER

kcharles@umich.edu
Melvin Stephens Jr. H. John Heinz III School of Public Policy and Management Carnegie Mellon University 4800 Forbes Avenue Pittsburgh, PA 15213 and NBER mstep@cmu.edu 


\section{Introduction}

This paper examines how the legalization of abortion in the early 1970s affected the tendency of children born during those years to drink, smoke, and use illicit substances as teenagers. Recent work on legalization's effects has focused on early life outcomes (Gruber, Levine and Staiger (1999)) as well as one later life activity - the propensity to commit serious crime (Donohue and Levitt (2001) and Joyce (2002)). ${ }^{1}$ Not only has a single later life outcome been studied, the two papers on legalization and crime reach dramatically different conclusions, making the impact of abortion reform on later life outcomes an open question. Our study focuses on a different outcome, about which there is likely independent interest and which, as we outline later, is ideal for assessing abortion legalization's later life effects.

Two main theoretical reasons have been posited for why abortion legalization could have affected later life outcomes like substance use and crime. One is the mechanism of selection - specifically, whether relatively disadvantaged women were more or less likely to have abortions after legalization. The early life circumstances of the average child born after legalization should have risen if they were and should have fallen otherwise. ${ }^{2}$ If a person's early life environment affects later life outcomes, selective use of abortion should have changed the incidence of bad teenage outcomes for persons born after abortion reform.

\footnotetext{
${ }^{1}$ There has also been work by Angrist and Evans (1999) on how abortion legalization affected human capital acquisition and labor market outcomes for potential mothers exposed to abortion reform.

${ }^{2}$ Selection of the first type could occur if adjusted their fertility to ensure that children are born when the mother's (or family's) economic position is most favorable. The second type of selection could occur is disadvantaged women lack the means to pay for abortions, or if they live relatively further from providers than their better off counterparts.
} 
The second mechanism does not depend on selection. Even if the fraction of children in a given cohort born into disadvantaged circumstances was unaffected by abortion availability, more abortions after legalization would have lowered the number of people at risk to engage in the relevant behavior. This reduction in the cohort size could affect the rate of use within a cohort because of how the costs that drug dealers face may change, how the distribution networks may operate, and how peer effects influence youth behaviors. $^{3}$

Several authors have shown that legalization was indeed associated with dramatic increases in the number of abortions (e.g., Bauman, Anderson, Freeman, and Koch (1977), and Levine, Kane, Staiger, and Zimmerman (1996)). ${ }^{4}$ With respect to the selective use of abortion, Levine et al. (1996) find that relatively disadvantaged groups such as teenagers, nonwhites, and unmarried women were more likely to have abortions after legalization. But they also find that older women, who tend not to be disadvantaged, were also more likely to have abortions after legalization. Moreover, even though groups like teenagers are more likely to be disadvantaged, there might have been systematic selection in the types of teenagers who had abortions. Hence, the conclusion that there was selective use of abortions by the disadvantaged may be tenuous.

Gruber, Levine, and Staiger (1999) study how legalization affected the circumstances into which a child was born. They show that children who would have been born but for abortion legalization would have been more likely to be born into poverty, to die in infancy, to receive welfare and to live in a single parent family. The

\footnotetext{
${ }^{3}$ Jacobson (2001) discusses these and other reasons why cohort size might affect the rate of use.

${ }^{4}$ The association between abortion availability and fertility has been found by many other authors. See Blank, George and London (1994), and Levine, Trainor and Zimmerman (1996), and Kane and Staiger (1996).
} 
improvement in the average early life circumstance of children born after abortion legalization supports the idea that there was positive selection (relatively more use by the disadvantaged) of abortion. ${ }^{5}$

Did the improvement in average childhood circumstances after legalization translate into better later-life outcomes for these children? Donohue and Levitt (2001) examine the relationship between legalization and the dramatic nationwide reduction in serious crime such as homicide, violent crime and property crime, which began in the early 1990s. There is a strong prima facie case that legalization had a causal effect on crime reduction. Crime began to fall abruptly and sharply in 1992, just as first cohorts born after legalization entered the prime crime-committing age range of 18-24. The reduction began earlier than 1992 in the five states that liberalized abortion prior to the Roe decision. ${ }^{6}$ Finally, the nationwide reduction continued through the early nineties, as the fraction of people aged 18 to 24 in any year who were born after legalization grew.

In their formal analysis, Donohue and Levitt relate changes over time in a state's abortion ratio (the proportion of abortions to live births) to crime within the state in the 1990s. They estimate a large effect: fully one-half of the reduction in crime can be explained by changes in the abortion ratio. This effect is larger than policy initiatives such as increased policing. Their evidence makes a compelling case for the notion that abortion legalization, presumably by virtue of its impact on the number and fraction of

\footnotetext{
${ }^{5}$ Other research finds a similar association between abortion access and improvements in birth outcomes. See for example, Grossman and Jacobowitz (1981), Grossman and Joyce (1990) and Currie, Nixon and Cole (1993).

${ }^{6}$ In 1970, four states explicitly legalized abortion by repealing state abortion laws. These states were New York, Washington, Alaska and Hawaii. A State Supreme Court ruling in late 1969 which held that existing anti-abortion laws were unconstitutional meant that, as of 1970, California was a state with "de facto" legalization.
} 
children born into disadvantaged circumstances, had a causal effect on subsequent criminal behavior.

Joyce (2001) also examines the relationship between legalization and crime. He is critical of Donohue and Levitt's analysis, and dubious of their conclusion that legalization lowered subsequent criminal activity. Joyce's main criticism centers on Donohue and Levitt's use of changes in the abortion ratio over time as their main source of variation. He argues that information on abortions may be unreliable, and that even if reliable, need not correlate neatly with unintended fertility. ${ }^{7}$ In addition, Donohue and Levitt's abortion ratio summarizes the number of abortions that occur within a state, which might be quite different from abortions had by women who live in the state.

Joyce uses an empirical strategy, previously employed by Gruber, Levine and Staiger (1999) and Angrist and Evans (1999), which exploits the fact that five states effectively legalized abortion three years before national legalization. The staggered nature of abortion legalization means that from 1970 to 1972, and only for those years, women in the five "repeal" states were exposed to legalized abortion while women in every other state were not. Joyce compares crime outcomes for people born in the 19701972 interval, across repeal and non-repeal states. He finds no evidence of a difference in crime between them, and concludes that relationship Donohue and Levitt find between crime and abortion ratios is spurious. ${ }^{8}$

\footnotetext{
${ }^{7}$ One explanation for this is that there may have been a correlation between the availability of abortion in a state and the use of contraceptives, or even the likelihood of engaging in sexual activity, for people in a state.

${ }^{8}$ Though they do not emphasize these results, Donohue and Levitt also use the repeal state/non repeal state comparison to study legalization and crime. Overall, their results from this exercise were mixed. Donohue and Levitt argue that the comparison of early versus late legalizers is not a useful approach in their context because the early legalizers have only a three year "head start". Since they study crime among a broad band of age cohorts, it is, in their view, difficult to identify any effect on overall crime.
} 
Because these studies of the subsequent criminal behavior of the cohorts exposed to abortion legalization gives mixed results, understanding whether the impact of abortion reform carries over to later life outcomes is an open, and important, topic to analyze. Here, we focus on adolescent use of controlled substances. ${ }^{9}$ Like serious crime, use by adolescents of controlled substances, particularly illicit narcotics, is likely a function of the person's childhood circumstances. Thus, any effect of abortion on early life environment should be manifested later in substance use. ${ }^{10}$ Also, particular features of available data on substance use make it a very interesting subject for the study of this effect.

One of these features is that national substance abuse trends among adolescents displayed a very different time series pattern to those for serious crime. Whereas crime began a sharp decrease in the early nineteen nineties, Figure 1 shows that the fraction of U.S. $12^{\text {th }}$ graders who report using controlled substances such as tobacco, alcohol and illegal substances like marijuana and cocaine started to trend upwards at around the same time. The figure shows only use patterns for use within the past month, but the patterns for having ever used the substances or for having used them within the past year are very similar. The pattern in Figure 1 is exactly the opposite of the first order relationship one might expect if legalization affected adolescent substance use. In light of these trends, formal evidence consistent with an effect of abortion would be quite convincing.

\footnotetext{
${ }^{9}$ Though this paper is about substance use and not crime, it should be noted that strictly speaking, a minor who uses any of the substances we study is engaged in criminal activity, albeit of a decidedly less serious variety than the types studied by Joyce and Donohue and Levitt. Also, substance use may be a gateway into serious criminal activity. For example see Markowitz (2000), Parker and Auerhahan (1998) and Baumer et al (1998).

${ }^{10}$ The relationship between background and family conditions has been documented by numerous authors. In Risky Behavior Among Youth: An Economic Analysis, Gruber ed., papers by Cook and Moore (alcohol), Gruber and Zinman (Smoking) and Pacula et al (marijuana use) estimate an a significant relationship between these factors and use.
} 
The most interesting aspect of studying substance use is that available data on this behavior permit a much sharper test of the effect of legalization than is possible with available crime data. Recall that the selection effect emphasized in the literature ought to have affected the rate at which people, born after legalization, engage in or manifest some negative outcome. Both Donohue and Levitt and Joyce, in their respective studies, use the Unified Crime Report data, compiled by the Federal Bureau of Investigation. These data measure all reported violent crime, property crime, and homicide. But because crime reports are not disaggregated by the age of the offender, they cannot be used in a proper test of abortion legalization: examining the impact on criminal activity by specific birth cohorts.

The other measures used in the crime studies to help get around this problem have equally serious limitations. One measure is the arrest rate, which is age-disaggregated. But the fact that a given number or fraction of people of a certain age are arrested for a particular type of crime in a year is, at best, a highly imperfect indicator of the number or fraction of persons of a given age who commit the particular crime in the year - the outcome of interest. Arrest rates depend on the actions of police, and are not conviction rates. Indeed, even if every arrested person were an offender, arrest rates by age might still systematically mis-measure criminal behavior by age if the capacity to escape arrest varies with age. Donohue and Levitt and Joyce also look at age-disaggregated crime victimization data. The limitations of these data for testing the prediction of the effect of legalization on criminal behavior are obvious. Crime victims are not criminal offenders, and even if they were, it is not clear how the ages of the two groups would line up. ${ }^{11}$

\footnotetext{
${ }^{11}$ Joyce also examines data from the FBI's Supplemental Homicide Reports.
} 
There are none of these problems with substance use data. As we discuss in detail below, we are able to examine the proportion of persons, from specific birth cohorts, who use controlled substances in a given year, at a particular age. In addition, because we use data from multiple years, there is little risk that our estimates conflate aging and time effects, as is possible with analyses similar to ours, but which use data from a single year. Gruber, Levine, and Staiger (1999), for example, in their analysis of the effect of legalization on early life outcomes, use data from the 1980 Census. The use of these data means that children born at different years are of different ages when observed in the data, making it difficult to separate aging and time effects. ${ }^{12}$

Using several generations of $12^{\text {th }}$ graders from the Monitoring the Future Survey, we classify adolescents by whether they were born in one of the states that legalized abortion before nationwide legalization in 1973 . For $12^{\text {th }}$ graders born in the same cohort, we then compare substance use between those born in repeal and other states. For cohorts born when abortion was legal in only the repeal states, we find that people born in those states were significantly less likely to use controlled substances, particularly the most serious like illegal narcotics, than persons from their birth cohorts born in other states. In addition, we find no evidence of differences in substance use by whether the person was born in a repeal state or not for cohorts born after national legalization.

We also examine how the probability of substance use was associated with changes in the birth rate to delineate between the impact on drug use due to selective use of abortion and that due to reductions in cohort size. When we isolate variation in birth rate due only to abortion legalization using an instrumental variables approach, we find

\footnotetext{
${ }^{12}$ Gruber, Kane and Staiger attempt to carefully deal with this potential problem by adding state-specific trends.
} 
that increases in birth rates are associated with increased probabilities of substance use. Since all the variation in birth rates in these results are induced by the abortion reforms, and since we find relatively sharp, cohort-specific changes in substance use as birth rates change, the results suggest a role for a selection effect above and beyond an effect due only to changes in cohort size.

We briefly discuss evidence about the abortion ratio and substance use, as there has been much controversy about the use of this ratio in the literature. We illustrate some problems with the abortion ratio, and explain why we are apprehensive about using it to identify the relationship of interest. It is noteworthy, however, that despite its problems the results from the abortion ratio essentially support the paper's main result: that in utero exposure to abortion legalization was associated with a reduction in the tendency to use, or to have ever used, controlled substances for $12^{\text {th }}$ grade adolescents.

In the next section we describe our empirical framework and the data in greater detail. Section 3 presents results from the differential timing of abortion reforms in the early legalizing states and national abortion legalization. In Section 4 we present the results using birth rates. Section 5 briefly discusses results when the abortion ratio is the regressor of interest and Section 6 concludes.

\section{Data and Empirical Framework}

We use data from several waves of the Monitoring the Future $(M T F)$ data set. The MTF is a repeated cross-sectional national survey that, since 1975 , has collected information each spring from high school seniors about their behaviors and attitudes. $M T F$ also surveys 8th and 10th graders although data collection for these two student 
groups did not commence until 1991. Our analysis focuses on the annual $12^{\text {th }}$ grade surveys because the late date at which data collection began for $8^{\text {th }}$ and $10^{\text {th }}$ graders makes it impossible to assess their substance prior to abortion legalization. The focus on different generations of $12^{\text {th }}$ graders means that we have a sample, drawn from different birth cohorts, who are (approximately) the same age when observed. Each cross-section of MTF $12^{\text {th }}$ graders consists of about 16,000 students from 130 schools (Johnston, O'Malley, and Bachman (2001)). ${ }^{13} \quad$ All of our analyses are weighted using the sampling weights provided with the study.

Information about the use of five types of controlled substances is available in the $M T F$. Information about three types comes directly from the $12^{\text {th }}$ graders' responses: use of cigarettes, use of alcohol, and use of marijuana. Information on other types of illicit substance use, such as cocaine, heroin, and amphetamines, is also collected in MTF. We use two composite measures constructed by the MTF staff. One indicates the use of any illicit drug; the other denotes use of any illicit drug excluding marijuana. For each of these five substances, we study two indicators of use. One indicates whether the student reports having ever used the substance at some point during his or her lifetime. The other measure, which likely better captures more habitual use, indicates whether the student used the substance within the past thirty days.

There is limited demographic data available in the MTF. We know the student's gender, whether the student is white, and the educational attainment of the student's

\footnotetext{
${ }^{13}$ One limitation of the data is that MTF does not sample high school dropouts. However, to the extent that dropouts are likely to be children born into relatively disadvantaged circumstances, their absence from the data biases us against finding evidence for the predicted effect of legalization.
} 
parents. ${ }^{14}$ Students who give missing responses for any of these demographic data are dropped from our analysis. ${ }^{15}$

Ideally, we would like to know each student's place and date of birth. The public use version of $M T F$ does not include state identifiers, but we made a restricted analysis data agreement with $M T F$ that enabled us to merge the student's state of residence as of the survey date onto the dataset. These state of residence identifiers are the only indication of student location available. Our analysis therefore assumes that the students' state of residence is the same as their state of birth - an assumption that is likely correct for the vast majority of the sample.

Students' birthdays are reported in the survey. We use this information to create a "year-of-birth" variable for each student which measures whether the student was exposed to legalized abortion in utero. Persons born in the early part of any year were in utero during the previous calendar year. Persons born in the latter half of any year were in utero during the calendar year of their birth. To line up children by their in utero exposure, we code each $M T F$ student's "year-of-birth" as year $t^{*}$ if the student was born between July 1 of year $t^{*}$ and June $30^{\text {th }}$ of year $t^{*}+1 .{ }^{16}$

Our analyses control for time-varying state-level factors that likely affect substance use. We use state cigarette and beer taxes, the fraction of the state's population that resides in a dry county, state per capita income, and state unemployment rate. Information on state cigarette taxes, including the federal cigarette tax, is from the

\footnotetext{
${ }^{14}$ Roughly $75 \%$ of our sample is white, $12 \%$ are African-American, $6 \%$ are Latin-American, and $2 \%$ are Asian-American.

${ }^{15}$ These exclusions result in a loss of nearly $10 \%$ of the observations. Additional results not shown here indicate that the results are not affected by deleting these observations.

${ }^{16}$ Constructing the year-of-birth variables this way also helps us align the students' years of birth with state abortion ratios, which we discuss in detail later.
} 
Tobacco Institute's The Tax Burden on Tobacco. ${ }^{17}$ The state tax on a case of twenty-four twelve-ounce beers was obtained from the Beer Institute's Brewer's Almanac. An estimate of the number of a state's residents residing in dry counties was also obtained from the Brewer's Almanac. Dividing these estimates by inter-censal estimates of the total population in a state taken from the Census Bureau, we create the fraction of the state population residing in dry counties for each year. Information on each state's annual per capita income was obtained from the Bureau of Economic Analysis, and state adult unemployment rates were obtained from the Bureau of Labor Statistics. All dollar figures are converted to 1999 dollars using the CPI-U.

\section{The Impact of Early vs. Late Legalization of Abortion}

Setup

Our first set of results exploits the fact that the "repeal" states legalized abortion three years prior to nationwide legalization in 1973. We estimate the model:

$$
\begin{aligned}
& \text { Use }_{i j t}=\beta_{1}\left(\text { Repeal }_{\mathrm{j}} * D_{7072}\right)+\beta_{2}\left(\text { Repeal }_{\mathrm{j}} * D_{7476}\right)+ \\
& \beta_{3} D_{7072}+\beta_{4} D_{7476}+\beta_{5} X_{i t}+\beta_{6} \Gamma_{j t}+\beta_{7} \delta_{j}+\beta_{8} \tau_{t}+\beta_{9} \mathrm{Coh}_{\mathrm{i}}+\varepsilon_{i j t} .
\end{aligned}
$$

where $\mathrm{Use}_{i j t}$ is an indicator variable which equals 1 if student $i$ in state $j$ in year $t$ uses the particular substance. The variables $X_{i t}$ and $\Gamma_{j t}$ are, respectively, the vectors of individual and time-varying state-level controls described above. The terms $\delta_{j}$ and $\tau_{t}$ are, respectively, state and survey year fixed effects whose inclusion in the model accounts for unobserved differences over time or across states which may be correlated

\footnotetext{
${ }^{17}$ Phil DeCicca graciously provided us these data. See DeCicca et al (2001) for the details of data construction.
} 
with the variables of interest. The binary variables $D_{7072}$ and $D_{7476}$ are year-of-birth dummies which indicate whether the person was born in the years 1970-1972 (as we have defined year of birth above) or was born in the years 1974-1976, respectively. We also include $\mathrm{Coh}_{\mathrm{i}}$ terms for each birth cohort to capture any additional differences across these cohorts. The variable Repeal ${ }_{j}$ in (1) denotes whether the person's state is one in which abortion was effectively legalized in $1970{ }^{18}$

The interactions between the two year-of-birth dummies and the repeal variable are the variables of interest in (1). The first interaction asks: Among persons born in 1970-1972, was adolescent substance use higher when they were high school seniors for those whose mothers were exposed to legalized abortion? The second interaction term asks: Among persons born in 1974-1976, whose mothers were all exposed to legalized abortion, was there a difference in adolescent use for those who happened to be born in states which had legalized abortion early? The fact that the data allows us to focus on substance use for people born in very specific birth cohorts, all at the same stage of life is a major strength of our analysis.

If abortion access affected substance use through either of the mechanisms described above, we would expect that among people who were born in 1970-1972, those from repeal states should have been less likely to use controlled substances as adolescents since only they were exposed to legalized abortion. The coefficient $\beta_{1}$ should thus be negative. By contrast, all individuals born in 1974-1976 were exposed to legalized

\footnotetext{
${ }^{18}$ The use of state fixed effects in equation (1) precludes the use of a main effect for the Repeal ${ }_{j}$ variable.
} 
abortion because of national legalization in 1973. We would thus expect that $\beta_{2}$ should be zero.

To estimate (1) we analyze cohorts of $12^{\text {th }}$ graders born over the interval 1966 to 1976. We exclude two birth cohorts: people who are born in years 1969 and 1973 . For these two cohorts it is not possible to say precisely what abortion regime prevailed during the time the person was in utero. With this modification, people in the sample were either exposed to legalized abortion in utero or not, and their exposure either arose because they were from a repeal state or not. Limiting our sample to these birth cohorts leads us to use individuals in the MTF spanning the survey years $1983-1999 .{ }^{19}$

\section{Basic Results}

Table 1 presents the results for whether students, as of their senior year in high school, report ever having used each of the five controlled substances. Means of the dependent variable as well as sample sizes are reported at the bottom of Table 1 for each dependent variable. ${ }^{20}$ Due to concerns about drawing correct inferences in models such as these, the reported standard errors allow for arbitrary correlation for individuals within the same state over time (Bertrand, Duflo, and Mullainathan 2002). The table shows that the demographic controls are all statistically significant determinants of substance use. Boys are more likely to have ever used all controlled substances, except tobacco. Controlling for family background, whites are more likely to have ever used. Increased parental education, both mother's and father's, reduces the likelihood of having ever used

\footnotetext{
${ }^{19}$ Nearly $99 \%$ of our sample is taken from the 1984-1995 surveys. Notice that these survey years correspond to the years when the birth cohorts are roughly 18 years of age.

${ }^{20}$ Sample sizes vary across dependent variables since students do not answer all substance use questions.
} 
the substance by $12^{\text {th }}$ grade across all categories of use, except for ever having drank alcohol.

Evidence about the effect of the time-varying state controls on ever having used any of the substances is mixed. The beer tax significantly lowers use of marijuana, any illicit drug and any illicit drug except marijuana, but has no significant effect on cigarette use and drinking. The cigarette tax does not affect whether $12^{\text {th }}$ graders have ever used any of the substances. The fraction of a state's population residing in a dry county as well as the state's per capita income both lower use for all of the substances although these estimates are not statistically significant in any regression. Finally, the state unemployment rate only significantly affects the most serious substance category - illicit drugs except marijuana.

The results show that for all of the more serious substances - marijuana, all illicit substances, and illicit substances excluding marijuana $-12^{\text {th }}$ graders who were exposed to legalized abortion in utero because their states were early legalizers were significantly less likely to have ever used. Not only are the effects strongly statistically significant, but they are economically meaningful as well. For example, $32 \%$ of students overall report ever having used an illicit drug other than marijuana. The estimated coefficient of -0.045 therefore implies a fifteen percent reduction in the likelihood of ever having used associated with in utero exposure to legal abortion. For the less serious categories cigarette smoking and drinking alcohol - the estimated effect on the interaction the same sign as for other substances, but are not significant.

The estimated effect for being born in a repeal state in 1974-1976 is not statistically different from zero in any of these "ever used" regressions. For these 
students who were all born after abortion was nationally legalized, there is no difference in the behavior of adolescents from repeal and non-repeal states. This result is precisely what one would expect given that students from both sets of states from these birth cohorts were exposed to legal abortions when in utero.

Table 2 presents the results for whether the student used substance within the last thirty days - the dimension of use that probably better captures habitual use. For all of the variables, the signs of the coefficients as well as their significance levels are virtually identical to the ever used results. The point estimates indicate a lower likelihood of recent substance use for the cohorts born in repeal states when only these states allowed abortion, with the strongest results occurring for the two most serious substance categories. Again, these results seem sensible; any effect of abortion exposure should affect most seriously the use of illegal drugs, and less dramatically substances like tobacco and alcohol which a large number of teens are likely to have recently used, irrespective of their backgrounds. In addition, as with the ever used results, we find no difference in the likelihood of recent use for persons born after 1973 between the two groups of states.

Overall, the results in Tables 1 and 2 are very consistent with the argument that early legalization, which exposed a subset of individuals to legalized abortion in utero, impacted the substance use of these individuals when they become adolescents. People born in repeal states in the three years of the "treatment" are less likely to use controlled substances as adolescents than are others in the same birth cohort who were born in states where abortion was illegal. There are no differences in outcomes for people born in the two types of states after national legalization, suggesting the differences in outcomes for 
people born in the "treatment" years is attributable to the different abortion regimes which existed in the two types of states in only these three years.

\section{Robustness Tests}

How sensitive are the results in Table 1 and Table 2 to alternative model specifications? The framework in (1) is a difference-in-difference estimator, with three distinct periods: the "before" period, when no person in utero in any state was exposed to legal abortion; the "during" period, when only persons in the repeal state were exposed to abortion; and the "after" period, when both the repeal and non-repeal states had legal abortion due to the national law change. The operating hypothesis within this framework is that, while there may be differences in factors that affect substance use between repeal and non-repeal states, these differences remain fixed across the three periods. The possibility that this hypothesis might not hold is why we control for time-varying statelevel factors. We assess the sensitivity of the results to the inclusion of these state-level controls, as well as the state, survey year, and cohort fixed effects.

Table 3 presents the estimated interaction effects from different versions of the model (1). The results in Panel A of the Table drop the survey year and cohort fixed effects from the model. ${ }^{21}$ The results in the Panel show that not accounting for secular trends in substance use, which equally affect all $12^{\text {th }}$ graders in a given year, does not change the estimated coefficients from those previously shown for the baseline regressions in Tables 1 and 2.

\footnotetext{
${ }^{21}$ While there is not an exact one-to-one correspondence between the survey year and cohort fixed effects, these coefficients exhibit a similar pattern when only one of these sets of effects is included in the model. Therefore, we only present the results when both sets of these effects are excluded.
} 
Panel B of Table 3 presents the results from excluding the state fixed effects from the model. In order to stay within the difference-in-difference framework, we include the binary variable Repeal $_{j}$ that takes the value one if the student resides in an early legalizing state and zero otherwise. In this specification, which does not account for permanent, unobserved differences across states that affect adolescent substance use, the results differ somewhat from those in the baseline model. The point estimates and significance of interaction terms in the "during period", when only repeal states have legalized abortion, are essentially unchanged - except that the estimated effect for marijuana is somewhat larger. The interactions for the "after" time period are different than the baseline results, none of which were statistically different from zero. Without fixed state controls, both alcohol "after" interactions are (weakly) significant as is the coefficient for recent use of illicit drugs except marijuana. Thus, dropping the state fixed effects has minor qualitative impacts on the results.

The third set of results drops the demographic and time-varying state controls from the baseline specification. Again, the results show that people born in repeal states in the during period (1970-1972) were less likely to use than were people born at the same time in other states. The estimated effects are quite similar (if not slightly larger in magnitude) to the baseline regressions. The results for the interactions in the after period, however, are dramatically different than both the baseline ever used and recently used results. When observable controls are dropped from the analysis, virtually all of the "after" interactions are large and statistically significant.

In Table 4, we explore why excluding the time-varying state controls might lead to significant coefficients for the after period. We focus on the time-varying state 
variables, as the demographic controls remain essentially constant across different waves of the survey. The entries on the left of the table are the average of the time-varying state controls, by repeal and non-repeal state, encountered by students during their $12^{\text {th }}$ grade year. ${ }^{22}$ The entries on the right show the difference-in-difference of these means between repeal and non-repeal states for people born across different pairs of time periods. If it were the case that the difference in the time-varying factors encountered by students born in the two types of states remains the same irrespective of when these students were born, the difference-in-difference terms would all equal zero.

The table shows that this condition is violated dramatically for all of state controls, across all pairs of time comparisons. For example, the average state unemployment rate confronted by students in the "after" period from repeal states versus those from non-repeal states is 2 percentage points higher than the comparable difference for students from repeal and non-repeal states born in the "before" period. To the extent that increased unemployment lowers student demand for drugs, the failure to control for this difference may impart a negative omitted variables bias for the estimated interaction term in the after period. Similar difference-in-difference results are evident for the other state controls, all of which will likely impart a negative bias on $\beta_{2}$. Thus, Table 4 strongly suggests the need to include these time-varying state controls.

In all likelihood, the results in Table 4 explain why, if the regressions do not control for time-varying state characteristics, we find greater substance use for people born in repeal states in the period when abortion was legal nationally. When the timevarying state controls are added, as is done in the baseline specification, the differential

\footnotetext{
${ }^{22}$ These averages are across the individuals in our dataset, not simply across the states in question.
} 
effect for people born after 1973 vanishes. Had the difference in use for people born from 1970-1972 only been due to changes in observable factors rather than to abortion legalization in the repeal states, we would not expect the estimated effect of Repeal $_{\mathrm{j}} * D_{7072}$ to be different than zero when the state-level controls are included. The fact that these interaction effects are not impacted by the inclusion of the state-level factors suggests that the estimated effects are truly due to differential abortion exposure.

\section{Analysis Using Birth Rate Variation}

The results in the previous section showed that children who were exposed to legalized abortions in utero because of early legalization were, on average, less likely to use controlled substances as adolescents. As we previously mentioned, abortion access could affect teen use through two mechanisms: an effect attributable purely to the fact that birth cohorts are made smaller by abortion, or the fact that the composition of cohorts changes after legalization because of greater use of abortion by relatively disadvantaged women (positive selection). In this section we analyze whether there is any evidence of a selection effect above and beyond a pure cohort size explanation for the results in the previous section.

Jacobsen (2001) argues that if fixed costs to selling illicit drugs are large, then an increase in the number of potential users in a cohort may lower drug prices due to economies of scale in distribution. In addition, if network effects play a role in acquiring or experimenting with drugs (i.e., it is easier to obtain drugs the larger your extended network of friends), then larger cohort sizes will increase the likelihood of teen substance use. Interestingly, all of these effects likely operate not only on the cohort that is smaller 
because of abortion, but also on surrounding birth cohorts. Students do not interact strictly within their own birth cohort, and drug dealers probably do not organize their sales on a cohort-by-cohort basis. Thus, the effect of legalization attributable purely to changes in cohort sizes should have created an externality that lowered use in the surrounding birth cohorts as well. By contrast, the effect of legalization attributable to the selection mechanism operates mainly for the particular cohort that is smaller as result of abortion. It follows that sharp changes in substance use corresponding to sharp changes in birth rates associated with legalization are suggestive of an effect of selection above and beyond a pure cohort size effect.

We can relate use to birth rates using the equation

$$
\mathrm{Use}_{i j t}=\alpha_{1} \text { Rate }_{j}+\alpha_{2} D_{7072}+\alpha_{3} D_{7476}+\alpha_{4} X_{i t}+\alpha_{5} \Gamma_{j t}+\alpha_{6} \delta_{j}+\alpha_{7} \tau_{t}+\alpha_{8} \operatorname{Coh}_{\mathrm{i}}+v_{i j t}
$$

where Rate $_{j}$ is the birth rate of the student's state (the number of live births per hundred women). In (2), the coefficient $\alpha_{1}$ measures how the probability that a teen from a given cohort uses controlled substances, is affected by the birth rate in his state when he was in utero. Unfortunately, the OLS coefficient on the birth rate in (2) does not estimate how birth rate changes induced by legalization affect use, since birth rates change over time for other reasons.

We are able to "tease out" the changes in the birth rates due to abortion legalization using the regression

$$
\begin{aligned}
\text { Rate }_{\mathrm{j}}=\gamma_{1}( & \text { Repeal } \left._{\mathrm{j}} * D_{7072}\right)+\gamma_{2}\left(\text { Repeal }_{\mathrm{j}} * D_{7476}\right) \\
& +\gamma_{3} D_{7072}+\gamma_{4} D_{7476}+\gamma_{5} X_{i t}+\gamma_{6} \Gamma_{j t}+\gamma_{7} \delta_{j}+\gamma_{8} \tau_{t}+\gamma_{9} \mathrm{Coh}_{\mathrm{i}}+u_{i j t} .
\end{aligned}
$$

Equation (3), in which the year-of-birth/repeal state interactions are used as instruments for the birth rate, isolates the portion of the birth rate variation due to the changes in 
abortion laws. When we subsequently use the predicted birth rate rather than the actual birth rate to estimate (2) by Two Stage Least Squares (TSLS), the coefficient $\alpha_{1}$ measures the impact of birth rates on substance use due solely to abortion legalization.

For the TSLS approach to tell us anything about whether legalization's effect on use derives in part from a selection effect, early legalization in the repeal states had to affect birth rates. Table 5 shows the results for the first stage equation, (3). We present results with and without the time-varying state controls for those students who responded to the ever smoked question. ${ }^{23}$ The results without observable state controls in column 1 show that from 1970-1972, birth rates in repeal states were more than 3 births per hundred women of childbearing age smaller than in the rest of the country. The effect is strongly statistically significant. In the period after national legalization, birth rates converged swiftly so there was no difference in birth rates between the two types of states. These results are nearly identical to those found by Levine et al (1996) who use a similar specification. ${ }^{24}$ The estimates that include all of the regressors used in the analysis in column 2 yield comparable results. We present this second set of results to highlight that the F-test for the excluded instruments shown at the bottom of Table 5 is large enough to avoid concerns about finite sample biases that may contaminate TSLS estimates (E.g., see Bound, Jaeger, and Baker 1995).

Table 5 shows that there were sharp changes in birth rates in repeal and nonrepeal states which correspond neatly with the changes in legalization in the two sets of

\footnotetext{
${ }^{23}$ There are virtually no differences in the results if we restrict the sample to those who respond to questions for the different dependent variables.

${ }^{24}$ Note that Levine et al perform their analysis at the state level while our analysis is perform at the individual level using our sample of MTF respondents. In addition, they use the log of the birth rate as the dependent variable rather than the level of the birth rate the level of the birth rate.
} 
states. Whether, in turn, part of the mechanism by which these legalization-induced changes in birth rates affected substance use operated through a selection effect above and beyond a pure cohort size effect, is indicated by the TSLS estimates. Specifically, if there was a selection effect, we would expect the TSLS estimates to show sharp changes in substance use which correspond to the changes in birth rate shown in Table 5. Notice, this evidence is different from the evidence of changes in use shown in the previous section, where we merely looked at categorical measures of legalization and there was no discussion of whether birth rates changed in a manner consistent with abortion access.

\section{Results}

Table 6 presents the OLS and TSLS results for the effect of birth rate on the probability that an adolescent used controlled substances using the same sample as in Section 3. In the OLS regressions, the birth rate has no effect on the probability of adolescent substance use for any of the controlled substances, in either category of use (ever or past 30 days). However, the point estimates are generally positive, as expected. As we argued above, these estimates contain variation in birth rates having nothing to do with legalization and thus do not answer the desired question.

The TSLS estimates where we instrument for birth rate using the abortion law reforms show a different outcome. Recall that these estimates isolate the variation in birth rate attributable to the abortion reforms. For the probability that a $12^{\text {th }}$ grader has ever used a substance, the TSLS estimates are statistically significant only for the illegal drug except marijuana category. The point estimates for ever having used marijuana or any illegal drug are positive, but not statistically significant. There is no effect on the 
probability of ever using marijuana or tobacco attributable to the changes in relative birth rates due to abortion legalization.

In many ways, the "ever use" dimension of use and some of the controlled substances, are not ideal for testing abortion's effects. For example, alcohol and tobacco are prominently and approvingly portrayed in film and other media, and are probably easily procurable during adolescence. Moreover, it may be that virtually all teenagers try these substances at least once as a rite of passage. If we do focus on the "ever use" dimension of use, the best substance on which to focus may be illegal drugs such as cocaine and amphetamines. Given their serious nature, they are the substances for which we would most expect legalization, operating through either the selection or cohort size effect, to matter. For these most serious substances, we estimate an increase in the probability of use attributable to the sudden and dramatic changes in birth rates following the abortion law changes.

For substance use in the past month, the TSLS estimates show that the increases in the birth rate due to legalization are associated with statistically significant increases in the probability of recent use for every substance except alcohol and marijuana. Even for these two substances, there is an estimate increase in the probability of recent use although the effects are not strongly significant. For each of the other categories, and especially for recent use of illegal drug except marijuana, we find large and strongly significant effects.

The TSLS results show that substance use changes sharply with legalizationinduced birth rates change. This evidence is different from that presented in the previous section, which showed only that substance use changed sharply with categorical measures 
of legalization. Legalization could have sharply changed some other factor, and it could be this other factor that accounts for that earlier evidence. The TSLS results show how use changed with changes in birth rate arising from legalization. These results indicate that above and beyond any pure cohort size effect on substance use following legalization, there was likely also a selection effect associated with these fertility reductions as well. Had there been no selection effect at all we would not expected the sharp patterns in the TSLS estimates. Our evidence is consistent with Gruber, Levine and Staiger (1996), who find cohort specific relative improvements for people from repeal states for early life outcomes, which also suggests a role for selection.

Our TSLS estimates imply that a 1 in 100 reduction in the birth rate stemming from legal abortion was associated in a 1 percentage point reduction in the probability of recent adolescent use of the illegal narcotics excluding marijuana. Relative to the mean rate of recent use found at the bottom of Table 2, this estimate represents a 10 percent reduction in the probability of use. One implication of this result is that the children who would have been born expect for legalization would have had a probability of using illegal narcotics which exceeded the use of people actually born by more than 10 percent. ${ }^{25}$ Furthermore, these results indicate that the patterns for national substance use depicted earlier in Figure 1, which began an upward trend in the early 1990's may have trended upwards even more had there been no abortion legalization.

\footnotetext{
${ }^{25}$ This calculation follows from the well-known results that the average of a variable (in this case the probability of use) rises only if the marginal change in the variable is greater than that average.
} 


\section{Estimates from Abortion Ratio Variation}

We noted earlier that the only later life outcome that has been previously studied is crime. Although we follow the other studies in the literature that focus on the impact of abortion legalization through the birth rate, we briefly discuss the abortion ratio in the context of our outcome variables because of the attention it has received in the crime studies. We discuss only the abortion ratio by state of residence - both because serious questions have been raised about the ratio by state of occurrence, and because the results for this other measure are virtually identical. ${ }^{26}$

Table 7 presents two sets of results. In the first panel, we present OLS and TSLS results for the effect of the abortion ratio on substance use. We show only the results for use within the past month. The OLS regression and TSLS regressions are identical to equations (2) and (3), except that we replace the birth rate in these equations with the abortion ratio. The second panel of Table 7 shows the first stage results. In these models, the "state of residence" abortion ratio equals the number of abortions had by women who live in a state, divided by the number of live births to women in that state. Total live births are measured from the year from July 1 to June 30, ensuring that the denominator corresponds to the same set of pregnancies as the numerator.

The first panel of the table shows that the estimated OLS effect of the abortion ratio on substance use is not significant for any of the controlled substances, except illicit drugs other than marijuana. For ease of interpretation, the abortion ratio has been divided

\footnotetext{
${ }^{26}$ Joyce (2001) criticizes the abortion ratio by state of occurrence because it includes abortions by people who do not live in the state. This consideration is a potentially important one in the years immediately preceding Roe v. Wade, since women from states that had not legalized abortion could travel into states in
} 
by 1000 in all of the regressions presented in the Panel A of Table 7. The TSLS estimates, by contrast, are all negative which means that increases in the abortion ratio are associated with lower use among $12^{\text {th }}$ graders who were exposed to this greater abortion activity in utero. In addition, the results are strongly significant for any illicit drug except marijuana and weakly significant for drinking and all illicit drug use.

Given these results, which are very consistent with the analogous results for birth rates presented in Table 5, why do we not emphasize the abortion ratio estimates? The answer is evident in the Panel B of Table 7. These first stage regressions show that the abortion ratio was higher in repeal states during the years when abortion was illegal in other states, as expected. However, the ratio continued to be higher in repeal states, even after abortion had been nationally legalized.

The elevated abortion ratio in repeal states relative to the rest of the country even after national legalization is why we do not emphasize the abortion ratio results, and is the crux of Joyce's criticism of Donohue and Levitt. If the only effect of legalized abortion was that it lowered birth rates, the first stage evidence for the abortion ratio should track that for the birth rate results presented earlier and there should be convergence in abortion ratios after national legalization. The fact that there are relatively more abortions in repeal states after national legalization raises the question about what treatment the abortion reform variables actually identify. It is clear the abortion ratio is does not only capture changes in unintended fertility - the assumption on which our technique hinges. With that in mind, it is very interesting that the abortion ratio results are qualitatively similar to both sets of our results.

which the abortion laws had been repealed to have the procedure performed. Ted Joyce graciously provided us with the "state of residence" abortion data used in our analysis. 


\section{Conclusion}

This paper studies the impact of abortion legalization on the use of controlled substances for people exposed to legalization in utero. Comparisons of teenage substance use for people born in states which legalized abortion early to use for youths from the same cohorts but from states both during the time when abortion was only legal in a subset of states and then again once abortion was nationally legalized show that in utero exposure to legalized abortion is associated with diminished substance use, especially of illegal narcotics.

We relate teen substance use to state birth rates and find no association in the simple correlation between these variables. However, when we focus only on that portion of the variation in birth rates attributable to the abortion reforms, we find the lower birth rates reduced teen substance use, but only for the very specific cohorts exposed to legalized abortion. That there is no effect for cohorts born just before or just after these particular cohorts indicates that the results derive at least in part from a selection effect which applied only to these specific cohorts, and not simply from cohort size effects which we do not expect to apply with the same cohort specificity.

Our paper undertakes none of the many philosophical and moral questions raised by abortion legalization and availability. Nor does our examination of the effect of abortion exposure on substance use address any of the other economic costs or gains associated with legalization. It would thus be wrong to read our results as supportive of abortion legalization in particular, or greater abortion availability in general. However, we believe that policy questions about abortion should be informed by credible estimates 
of the policy's various effects. Research that examines additional later life outcomes attributable to the reforms in abortion laws, both within the United States as well as in other countries, is needed to provide a more complete picture of the impact of such laws. 


\section{Bibliography}

Angrist, Joshua D. and William Evans, 1999, "Schooling and Labor Market Consequences of the 1970 State Abortion Reforms," in Polachek, Solomon W., ed. Research in Labor Economics, Volume 18 75-113, 75-113.

Baumer, E., J.L. Lauritsen, R. Rosenfeld, and R. Wright, 1998, “The Influence of Crack Cocaine on Robbery, Burglary, and Homicide Rates: A Cross-City Longitudinal Analysis," Journal of Research on Crime and Delinquency, 35, 316-340.

Beer Institute. Brewers' Almanac. New York, NY: United States Brewers Foundation, Various Years.

Bertrand, Marianne, Esther Duflo, and Sendhil Mullainathan, 2002, "How Much Should We Trust Differences-in-Differences Estimates?" National Bureau of Economic Research Working Paper, \#8841.

Blank, Rebecca, C. C. George, and Rebecca A. London, "State Abortion Rates: The Impact of Policies, Providers, Demographics, and Economic Environment, " Journal of Health Economics, Vol. 15. (Fall 1996), 513-53.

Bound, John, David A. Jaeger, and Regina M. Baker, "Problems with Instrumental Variables Estimation When the Correlation Between the Instruments and the Endogeneous Explanatory Variable is Weak," Journal of the American Statistical Association, 90(430). (June 1995), 443-50.

Brown, Sarah S. and Lean EiseNational Bureau of Economic Researchg, 1995. The Best Intentions: Unintended Pregnancy and the Well Being of Children and Families, Washington, D.C. National Academy Press.

Currie, Janet, Lucia Nixon and Nancy Cole, 1996, "Restrictions on Medicaid Funding of Abortion," Journal of Human Resources, 31, pp. 159-188.

Donohue, John and Steven Levitt, 2001, “The Impact of Legalized Abortion on Crime", Quarterly Journal of Economics, 116(2), 379-420.

Grossman, Michael and Steven Jacobowitz, 1981, "Variations in Infant Mortality Rates Among Counties in the United States: The Roles of Public Policies and Programs," Demography, XVIII(4), 695-713.

Grossman, Michael and Theodore Joyce, 1990, "Unobservables, Pregnancy Resolutions, and Birth Weight Production Functions in New York City," Journal of Political Economy, 98 (5), Pt. 1, 983-1007. 
Gruber, Jonathan and Phillip Levine and Douglas Staiger, 1999, "Abortion Legalization and Child Living Circumstances: Who is the Marginal Child?", Quarterly Journal of Economics; 114(1), 263-91.

Gruber, Jonathan eds. 2001. Risky Behavior Among Youths: An Economic Analysis. University of Chicago Press.

Jacobson, Mireille, 2001, "Baby Booms and Drug Busts: Trends in Youth Drug Use in the United States, 1975-2000," Unpublished Manuscript, Harvard University.

Johnston, Lloyd D., Patrick M. O'Malley, and Jerald G. Bachman. 2001. National Survey Results on Drug Use from the Monitoring the Future Study, 1975-2000 Volume I: Secondary School Students (NIH Publication No. 01-4924). Bethesda, MD: National Institute on Drug Abuse.

Jones, Elise F. and Jacqueline D. Forrest, 1992 "Underreporting of Abortion in Surveys of U.S. Women: 1976 to 1988,” Demography, 24, 113-126.

Joyce, Theodore, 2001, "Did Legalized Abortion Lower Crime?" National Bureau of Economic Research Working Paper, \#8319.

Kane, Thomas and Douglas Staiger, 1996, "Teen Motherhood and Abortion Access", Quarterly Journal of Economics, 111(2), 467-506.

Levine, Phil, Douglas Staiger, Tom Kane, and David Zimmerman, 1996 "Roe v. Wade and American Fertility, National Bureau of Economic Research Working Paper, \# 5615.

Markowitz, Sara, 2000, "The Role of Alcohol and Drug Consumption in Determining Physical Fights and Weapon Carrying by Teenagers," National Bureau of Economic Research Working Paper \#7500.

Parker, R and K. Auerhahan, 1998, "Alcohol, Drugs and Violence," Annual Review of Sociology, 24, 291-311.

Sklar, June and Beth Berkov, 1974, "Abortion, Illegitimacy, and the American Birth Rate," Science, 1985 , September 13.

Tobacco Institute. Tax Burden on Tobacco. Richmond, VA: Tobacco Institute. Various Years. 
Table 1. Reduced Form Estimates of Effect of in utero Legalized Abortion Exposure on Whether Ever Used Controlled Substance

\begin{tabular}{|c|c|c|c|c|c|}
\hline Variable & $\underline{\text { Smoke }}$ & $\underline{\text { Drink }}$ & $\begin{array}{l}\text { 'ontrolled } S u \\
\text { Marijuana }\end{array}$ & $\begin{array}{c}\text { Any } \\
\text { Illicit Drug }\end{array}$ & $\begin{array}{l}\text { Any Illicit Drug } \\
\text { Except Marijuana }\end{array}$ \\
\hline Repeal*D_7072 & $\begin{array}{l}-0.017 \\
(0.015)\end{array}$ & $\begin{array}{l}-0.009 \\
(0.008)\end{array}$ & $\begin{array}{l}-0.038 \\
(0.015)\end{array}$ & $\begin{array}{l}-0.033 \\
(0.014)\end{array}$ & $\begin{array}{l}-0.045 \\
(0.011)\end{array}$ \\
\hline Repeal*D_7476 & $\begin{array}{l}-0.010 \\
(0.026)\end{array}$ & $\begin{array}{l}-0.021 \\
(0.019)\end{array}$ & $\begin{array}{l}-0.008 \\
(0.033)\end{array}$ & $\begin{array}{l}-0.012 \\
(0.035)\end{array}$ & $\begin{array}{l}-0.022 \\
(0.025)\end{array}$ \\
\hline D_7072 & $\begin{array}{l}-0.044 \\
(0.022)\end{array}$ & $\begin{array}{c}0.028 \\
(0.017)\end{array}$ & $\begin{array}{l}-0.035 \\
(0.025)\end{array}$ & $\begin{array}{l}-0.040 \\
(0.024)\end{array}$ & $\begin{array}{l}-0.060 \\
(0.020)\end{array}$ \\
\hline D_7476 & $\begin{array}{l}-0.101 \\
(0.038)\end{array}$ & $\begin{array}{c}0.052 \\
(0.021)\end{array}$ & $\begin{array}{l}-0.170 \\
(0.034)\end{array}$ & $\begin{array}{l}-0.181 \\
(0.033)\end{array}$ & $\begin{array}{l}-0.159 \\
(0.030)\end{array}$ \\
\hline Male & $\begin{array}{l}-0.008 \\
(0.010)\end{array}$ & $\begin{array}{c}0.007 \\
(0.003)\end{array}$ & $\begin{array}{c}0.064 \\
(0.008)\end{array}$ & $\begin{array}{c}0.037 \\
(0.007)\end{array}$ & $\begin{array}{c}0.001 \\
(0.004)\end{array}$ \\
\hline White & $\begin{array}{c}0.113 \\
(0.008)\end{array}$ & $\begin{array}{c}0.069 \\
(0.005)\end{array}$ & $\begin{array}{c}0.079 \\
(0.017)\end{array}$ & $\begin{array}{c}0.085 \\
(0.015)\end{array}$ & $\begin{array}{c}0.104 \\
(0.009)\end{array}$ \\
\hline Mother HS Grad & $\begin{array}{l}-0.027 \\
(0.006)\end{array}$ & $\begin{array}{c}0.007 \\
(0.006)\end{array}$ & $\begin{array}{l}-0.025 \\
(0.011)\end{array}$ & $\begin{array}{l}-0.029 \\
(0.010)\end{array}$ & $\begin{array}{l}-0.034 \\
(0.007)\end{array}$ \\
\hline Mother Some College & $\begin{array}{l}-0.031 \\
(0.005)\end{array}$ & $\begin{array}{c}0.016 \\
(0.006)\end{array}$ & $\begin{array}{l}-0.011 \\
(0.012)\end{array}$ & $\begin{array}{l}-0.017 \\
(0.010)\end{array}$ & $\begin{array}{l}-0.028 \\
(0.008)\end{array}$ \\
\hline Mother College Grad & $\begin{array}{l}-0.035 \\
(0.007)\end{array}$ & $\begin{array}{c}0.005 \\
(0.005)\end{array}$ & $\begin{array}{l}-0.034 \\
(0.012)\end{array}$ & $\begin{array}{l}-0.043 \\
(0.011)\end{array}$ & $\begin{array}{l}-0.049 \\
(0.009)\end{array}$ \\
\hline Father HS Grad & $\begin{array}{l}-0.032 \\
(0.005)\end{array}$ & $\begin{array}{c}0.004 \\
(0.003)\end{array}$ & $\begin{array}{l}-0.019 \\
(0.007)\end{array}$ & $\begin{array}{l}-0.023 \\
(0.006)\end{array}$ & $\begin{array}{l}-0.024 \\
(0.004)\end{array}$ \\
\hline Father Some College & $\begin{array}{l}-0.037 \\
(0.005)\end{array}$ & $\begin{array}{c}0.011 \\
(0.004)\end{array}$ & $\begin{array}{l}-0.023 \\
(0.007)\end{array}$ & $\begin{array}{l}-0.020 \\
(0.006)\end{array}$ & $\begin{array}{l}-0.023 \\
(0.005)\end{array}$ \\
\hline Father College Grad & $\begin{array}{l}-0.055 \\
(0.005)\end{array}$ & $\begin{array}{l}-0.003 \\
(0.004)\end{array}$ & $\begin{array}{l}-0.032 \\
(0.007)\end{array}$ & $\begin{array}{l}-0.036 \\
(0.007)\end{array}$ & $\begin{array}{l}-0.036 \\
(0.006)\end{array}$ \\
\hline $\begin{array}{l}\text { Cigarette Tax } \\
\text { (in dollars) }\end{array}$ & $\begin{array}{l}-0.005 \\
(0.071)\end{array}$ & $\begin{array}{l}-0.017 \\
(0.043)\end{array}$ & $\begin{array}{c}0.058 \\
(0.057)\end{array}$ & $\begin{array}{c}0.051 \\
(0.054)\end{array}$ & $\begin{array}{c}0.043 \\
(0.046)\end{array}$ \\
\hline $\begin{array}{l}\text { Beer Tax } \\
\text { (in dollars) }\end{array}$ & $\begin{array}{l}-0.029 \\
(0.027)\end{array}$ & $\begin{array}{l}-0.009 \\
(0.017)\end{array}$ & $\begin{array}{l}-0.120 \\
(0.036)\end{array}$ & $\begin{array}{l}-0.087 \\
(0.033)\end{array}$ & $\begin{array}{l}-0.049 \\
(0.032)\end{array}$ \\
\hline Fraction Dry & $\begin{array}{l}-0.199 \\
(0.326)\end{array}$ & $\begin{array}{l}-0.139 \\
(0.189)\end{array}$ & $\begin{array}{l}-0.066 \\
(0.351)\end{array}$ & $\begin{array}{l}-0.178 \\
(0.334)\end{array}$ & $\begin{array}{l}-0.050 \\
(0.466)\end{array}$ \\
\hline $\begin{array}{l}\text { State Per Capita Income } \\
\text { (in } \$ 10,000 \text { ) }\end{array}$ & $\begin{array}{l}-0.012 \\
(0.048)\end{array}$ & $\begin{array}{c}0.040 \\
(0.035)\end{array}$ & $\begin{array}{l}-0.042 \\
(0.073)\end{array}$ & $\begin{array}{l}-0.038 \\
(0.075)\end{array}$ & $\begin{array}{l}-0.047 \\
(0.059)\end{array}$ \\
\hline State Unemployment Rate & $\begin{array}{l}-0.0014 \\
(0.0029)\end{array}$ & $\begin{array}{c}0.000004 \\
(0.001787)\end{array}$ & $\begin{array}{l}-0.0008 \\
(0.0042)\end{array}$ & $\begin{array}{c}-0.0023 \\
(0.0041)\end{array}$ & $\begin{array}{c}-0.0092 \\
(0.0039)\end{array}$ \\
\hline State Fixed Effects? & Yes & Yes & Yes & Yes & Yes \\
\hline Survey Year Fixed Effects? & Yes & Yes & Yes & Yes & Yes \\
\hline Cohort Fixed Effects? & Yes & Yes & Yes & Yes & Yes \\
\hline Mean of Dependent Var & 0.65 & 0.89 & 0.44 & 0.51 & 0.32 \\
\hline R-squared & 0.02 & 0.045 & 0.043 & 0.035 & 0.028 \\
\hline $\mathrm{N}$ & 126,504 & 117,260 & 126,116 & 124,699 & 124,699 \\
\hline
\end{tabular}

Regressions are weighted using MTF sampling weights.

Standard errors allow for arbitrary clustering within a state. See text for additional details. 
Table 2. Reduced Form Estimates of Effect of in utero Legalized Abortion Exposure on Whether Used Controlled Substance Within Last Month

\begin{tabular}{|c|c|c|c|c|c|}
\hline Variable & $\underline{\text { Smoke }}$ & $\underline{\text { Drink }}$ & ontrolled Su & $\begin{array}{c}\text { Any } \\
\text { Illicit Drug }\end{array}$ & $\begin{array}{l}\text { Any Illicit Drug } \\
\text { Except Marijuana }\end{array}$ \\
\hline Repeal*D_7072 & $\begin{array}{l}-0.020 \\
(0.013)\end{array}$ & $\begin{array}{l}-0.030 \\
(0.016)\end{array}$ & $\begin{array}{l}-0.013 \\
(0.011)\end{array}$ & $\begin{array}{l}-0.024 \\
(0.013)\end{array}$ & $\begin{array}{l}-0.034 \\
(0.010)\end{array}$ \\
\hline Repeal*D_7476 & $\begin{array}{c}0.008 \\
(0.027)\end{array}$ & $\begin{array}{l}-0.013 \\
(0.033)\end{array}$ & $\begin{array}{c}0.006 \\
(0.024)\end{array}$ & $\begin{array}{c}0.005 \\
(0.029)\end{array}$ & $\begin{array}{l}-0.003 \\
(0.015)\end{array}$ \\
\hline D_7072 & $\begin{array}{l}-0.094 \\
(0.023)\end{array}$ & $\begin{array}{l}-0.005 \\
(0.025)\end{array}$ & $\begin{array}{l}-0.018 \\
(0.015)\end{array}$ & $\begin{array}{l}-0.012 \\
(0.017)\end{array}$ & $\begin{array}{l}-0.014 \\
(0.013)\end{array}$ \\
\hline D_7476 & $\begin{array}{l}-0.192 \\
(0.040)\end{array}$ & $\begin{array}{l}-0.070 \\
(0.034)\end{array}$ & $\begin{array}{l}-0.048 \\
(0.022)\end{array}$ & $\begin{array}{l}-0.048 \\
(0.024)\end{array}$ & $\begin{array}{l}-0.029 \\
(0.018)\end{array}$ \\
\hline Male & $\begin{array}{l}-0.008 \\
(0.009)\end{array}$ & $\begin{array}{c}0.081 \\
(0.006)\end{array}$ & $\begin{array}{c}0.057 \\
(0.004)\end{array}$ & $\begin{array}{c}0.049 \\
(0.004)\end{array}$ & $\begin{array}{c}0.019 \\
(0.002)\end{array}$ \\
\hline White & $\begin{array}{c}0.127 \\
(0.009)\end{array}$ & $\begin{array}{c}0.170 \\
(0.011)\end{array}$ & $\begin{array}{c}0.049 \\
(0.010)\end{array}$ & $\begin{array}{c}0.059 \\
(0.010)\end{array}$ & $\begin{array}{c}0.038 \\
(0.004)\end{array}$ \\
\hline Mother HS Grad & $\begin{array}{l}-0.022 \\
(0.007)\end{array}$ & $\begin{array}{c}0.015 \\
(0.007)\end{array}$ & $\begin{array}{l}-0.005 \\
(0.006)\end{array}$ & $\begin{array}{l}-0.009 \\
(0.007)\end{array}$ & $\begin{array}{l}-0.011 \\
(0.004)\end{array}$ \\
\hline Mother Some College & $\begin{array}{l}-0.031 \\
(0.008)\end{array}$ & $\begin{array}{c}0.020 \\
(0.008)\end{array}$ & $\begin{array}{c}0.000 \\
(0.007)\end{array}$ & $\begin{array}{l}-0.005 \\
(0.008)\end{array}$ & $\begin{array}{l}-0.009 \\
(0.004)\end{array}$ \\
\hline Mother College Grad & $\begin{array}{l}-0.032 \\
(0.008)\end{array}$ & $\begin{array}{c}0.023 \\
(0.010)\end{array}$ & $\begin{array}{l}-0.008 \\
(0.007)\end{array}$ & $\begin{array}{l}-0.013 \\
(0.008)\end{array}$ & $\begin{array}{l}-0.015 \\
(0.004)\end{array}$ \\
\hline Father HS Grad & $\begin{array}{l}-0.019 \\
(0.007)\end{array}$ & $\begin{array}{l}-0.006 \\
(0.005)\end{array}$ & $\begin{array}{l}-0.013 \\
(0.006)\end{array}$ & $\begin{array}{l}-0.013 \\
(0.006)\end{array}$ & $\begin{array}{l}-0.013 \\
(0.004)\end{array}$ \\
\hline Father Some College & $\begin{array}{l}-0.027 \\
(0.008)\end{array}$ & $\begin{array}{l}-0.005 \\
(0.008)\end{array}$ & $\begin{array}{l}-0.007 \\
(0.006)\end{array}$ & $\begin{array}{l}-0.010 \\
(0.005)\end{array}$ & $\begin{array}{l}-0.014 \\
(0.004)\end{array}$ \\
\hline Father College Grad & $\begin{array}{l}-0.035 \\
(0.009)\end{array}$ & $\begin{array}{c}0.001 \\
(0.007)\end{array}$ & $\begin{array}{l}-0.007 \\
(0.005)\end{array}$ & $\begin{array}{l}-0.011 \\
(0.006)\end{array}$ & $\begin{array}{l}-0.015 \\
(0.004)\end{array}$ \\
\hline $\begin{array}{l}\text { Cigarette Tax } \\
\text { (in dollars) }\end{array}$ & $\begin{array}{l}-0.008 \\
(0.071)\end{array}$ & $\begin{array}{l}-0.019 \\
(0.058)\end{array}$ & $\begin{array}{c}0.007 \\
(0.037)\end{array}$ & $\begin{array}{c}0.000 \\
(0.035)\end{array}$ & $\begin{array}{c}0.004 \\
(0.019)\end{array}$ \\
\hline $\begin{array}{l}\text { Beer Tax } \\
\text { (in dollars) }\end{array}$ & $\begin{array}{l}-0.031 \\
(0.025)\end{array}$ & $\begin{array}{l}-0.014 \\
(0.040)\end{array}$ & $\begin{array}{l}-0.088 \\
(0.027)\end{array}$ & $\begin{array}{l}-0.085 \\
(0.034)\end{array}$ & $\begin{array}{l}-0.036 \\
(0.025)\end{array}$ \\
\hline Fraction Dry & $\begin{array}{c}0.050 \\
(0.328)\end{array}$ & $\begin{array}{l}-0.795 \\
(0.333)\end{array}$ & $\begin{array}{l}-0.446 \\
(0.291)\end{array}$ & $\begin{array}{l}-0.403 \\
(0.275)\end{array}$ & $\begin{array}{c}0.097 \\
(0.254)\end{array}$ \\
\hline $\begin{array}{l}\text { State Per Capita Income } \\
\text { (in } \$ 10,000 \text { ) }\end{array}$ & $\begin{array}{l}-0.018 \\
(0.050)\end{array}$ & $\begin{array}{c}0.012 \\
(0.059)\end{array}$ & $\begin{array}{l}-0.050 \\
(0.054)\end{array}$ & $\begin{array}{l}-0.036 \\
(0.061)\end{array}$ & $\begin{array}{l}-0.015 \\
(0.050)\end{array}$ \\
\hline State Unemployment Rate & $\begin{array}{l}-0.0030 \\
(0.0028)\end{array}$ & $\begin{array}{l}-0.0031 \\
(0.0038)\end{array}$ & $\begin{array}{c}0.0023 \\
(0.0029)\end{array}$ & $\begin{array}{l}-0.0013 \\
(0.0032)\end{array}$ & $\begin{array}{l}-0.0058 \\
(0.0038)\end{array}$ \\
\hline State Fixed Effects? & Yes & Yes & Yes & Yes & Yes \\
\hline Survey Year Fixed Effects? & Yes & Yes & Yes & Yes & Yes \\
\hline Cohort Fixed Effects? & Yes & Yes & Yes & Yes & Yes \\
\hline Mean of Dependent Var & 0.30 & 0.60 & 0.19 & 0.22 & 0.10 \\
\hline R-squared & 0.026 & 0.061 & 0.029 & 0.028 & 0.017 \\
\hline $\mathrm{N}$ & 126,389 & 116,751 & 125,674 & 122,867 & 122,867 \\
\hline
\end{tabular}

Regressions are weighted using MTF sampling weights.

Standard errors allow for arbitrary clustering within a state. See text for additional details. 


\begin{tabular}{|c|c|c|c|c|c|c|}
\hline \multirow{2}{*}{ Robustness Test } & & \multicolumn{5}{|c|}{ Controlled Substance } \\
\hline & & Smoke & $\underline{\text { Drink }}$ & Marijuana & $\begin{array}{c}\text { Any } \\
\text { Illicit Drug }\end{array}$ & $\begin{array}{l}\text { Any Illicit Drug } \\
\text { Except Marijuan }\end{array}$ \\
\hline \multirow[t]{3}{*}{ A. Drop Survey Year And Cohort Fixed Effects } & Interaction Terms & & & & & \\
\hline & Repeal*D_7072 & $\begin{array}{l}-0.016 \\
(0.015)\end{array}$ & $\begin{array}{l}-0.002 \\
(0.008)\end{array}$ & $\begin{array}{l}-0.034 \\
(0.017)\end{array}$ & $\begin{array}{l}-0.030 \\
(0.016)\end{array}$ & $\begin{array}{l}-0.044 \\
(0.010)\end{array}$ \\
\hline & Repeal*D_7476 & $\begin{array}{l}-0.004 \\
(0.025)\end{array}$ & $\begin{array}{l}-0.037 \\
(0.024)\end{array}$ & $\begin{array}{c}0.002 \\
(0.035)\end{array}$ & $\begin{array}{l}-0.006 \\
(0.036)\end{array}$ & $\begin{array}{l}-0.028 \\
(0.023)\end{array}$ \\
\hline Use in Past Month? & Repeal*D_7072 & $\begin{array}{l}-0.022 \\
(0.013)\end{array}$ & $\begin{array}{l}-0.021 \\
(0.016)\end{array}$ & $\begin{array}{l}-0.013 \\
(0.013)\end{array}$ & $\begin{array}{l}-0.024 \\
(0.014)\end{array}$ & $\begin{array}{l}-0.035 \\
(0.011)\end{array}$ \\
\hline & Repeal*D_7476 & $\begin{array}{c}0.023 \\
(0.026)\end{array}$ & $\begin{array}{l}-0.010 \\
(0.035)\end{array}$ & $\begin{array}{c}0.011 \\
(0.024)\end{array}$ & $\begin{array}{c}0.006 \\
(0.028)\end{array}$ & $\begin{array}{l}-0.011 \\
(0.015)\end{array}$ \\
\hline \multicolumn{7}{|l|}{ B. Drop State Fixed Effects } \\
\hline Ever Use? & Repeal*D_7072 & $\begin{array}{l}-0.020 \\
(0.012)\end{array}$ & $\begin{array}{l}-0.022 \\
(0.007)\end{array}$ & $\begin{array}{l}-0.049 \\
(0.027)\end{array}$ & $\begin{array}{l}-0.039 \\
(0.022)\end{array}$ & $\begin{array}{l}-0.044 \\
(0.011)\end{array}$ \\
\hline & Repeal*D_7476 & $\begin{array}{l}-0.019 \\
(0.017)\end{array}$ & $\begin{array}{l}-0.043 \\
(0.014)\end{array}$ & $\begin{array}{l}-0.032 \\
(0.024)\end{array}$ & $\begin{array}{l}-0.023 \\
(0.026)\end{array}$ & $\begin{array}{l}-0.028 \\
(0.019)\end{array}$ \\
\hline Use in Past Month? & Repeal*D_7072 & $\begin{array}{l}-0.025 \\
(0.009)\end{array}$ & $\begin{array}{l}-0.053 \\
(0.023)\end{array}$ & $\begin{array}{l}-0.027 \\
(0.019)\end{array}$ & $\begin{array}{l}-0.038 \\
(0.018)\end{array}$ & $\begin{array}{l}-0.037 \\
(0.008)\end{array}$ \\
\hline & Repeal*D_7476 & $\begin{array}{c}0.004 \\
(0.016)\end{array}$ & $\begin{array}{c}-0.048 \\
(0.027)\end{array}$ & $\begin{array}{c}-0.016 \\
(0.020)\end{array}$ & $\begin{array}{c}-0.023 \\
(0.021)\end{array}$ & $\begin{array}{c}-0.022 \\
(0.013)\end{array}$ \\
\hline \multicolumn{7}{|c|}{ C. Drop Demographic and Time-Varying State Controls } \\
\hline Ever Use? & Repeal*D_7072 & $\begin{array}{l}-0.022 \\
(0.010)\end{array}$ & $\begin{array}{l}-0.012 \\
(0.005)\end{array}$ & $\begin{array}{l}-0.049 \\
(0.021)\end{array}$ & $\begin{array}{l}-0.041 \\
(0.017)\end{array}$ & $\begin{array}{l}-0.050 \\
(0.010)\end{array}$ \\
\hline & Repeal*D_7476 & $\begin{array}{l}-0.032 \\
(0.020)\end{array}$ & $\begin{array}{l}-0.042 \\
(0.019)\end{array}$ & $\begin{array}{l}-0.058 \\
(0.026)\end{array}$ & $\begin{array}{l}-0.051 \\
(0.027)\end{array}$ & $\begin{array}{l}-0.060 \\
(0.022)\end{array}$ \\
\hline Use in Past Month? & Repeal*D_7072 & $\begin{array}{l}-0.027 \\
(0.007)\end{array}$ & $\begin{array}{l}-0.036 \\
(0.019)\end{array}$ & $\begin{array}{l}-0.027 \\
(0.014)\end{array}$ & $\begin{array}{l}-0.040 \\
(0.013)\end{array}$ & $\begin{array}{l}-0.042 \\
(0.009)\end{array}$ \\
\hline & Repeal*D_7476 & $\begin{array}{l}-0.021 \\
(0.020)\end{array}$ & $\begin{array}{l}-0.057 \\
(0.032)\end{array}$ & $\begin{array}{c}-0.032 \\
(0.014)\end{array}$ & $\begin{array}{c}-0.043 \\
(0.017)\end{array}$ & $\begin{array}{c}-0.034 \\
(0.015)\end{array}$ \\
\hline
\end{tabular}

The regressions from which these estimates come are identical to the regressions in Tables 1 and 2 , except for the specific modification noted

Data from multiple waves of Monitoring the Future. See text for additional details.

Regressions are weighted using MTF sampling weights.

In Panel A, survey year and cohort fixed effects are dropped. However, the year of birth main effects D 7072 and D 7476 remain in the analysis.

In Panel B, state fixed effects are dropped. However, the dummy variable Repeal, which is 1 if the student resides in a repeal state and 0 otherwise, is included. 
Table 4. Difference-in-Differences of Time-Varying State Controls

Compare Repeal versus Non-Repeal States and by Period of Birth.

"Before" is "Prior to 1970", "During" is 1970-1972, "After" is 1974-1976.

\begin{tabular}{|c|c|c|c|c|c|c|}
\hline \multirow[b]{2}{*}{$\begin{array}{l}\text { Variable } \\
\text { State Unemployment Rat }\end{array}$} & \multicolumn{3}{|c|}{ Mean by Birth Interval } & \multicolumn{3}{|c|}{$\underline{\text { Difference in Difference }}$} \\
\hline & $\underline{\text { Before }}$ & $\underline{\text { During }}$ & $\underline{\text { After }}$ & $\underline{\text { Dur-Bef }}$ & After-Dur & $\underline{\text { After-Bef }}$ \\
\hline Repeal & $\begin{array}{c}6.7 \\
(0.01)\end{array}$ & $\begin{array}{c}5.9 \\
(0.01)\end{array}$ & $\begin{array}{c}8.0 \\
(0.01)\end{array}$ & & & \\
\hline Non-Repeal & $\begin{array}{c}7.0 \\
(0.01)\end{array}$ & $\begin{array}{c}5.8 \\
(0.01)\end{array}$ & $\begin{array}{c}6.0 \\
(0.01)\end{array}$ & $\begin{array}{c}0.3 \\
(0.02)\end{array}$ & $\begin{array}{c}1.9 \\
(0.02)\end{array}$ & $\begin{array}{c}2.3 \\
(0.02)\end{array}$ \\
\hline
\end{tabular}

Fraction Dry Population

$\begin{array}{lcccccc}\text { Repeal } & 0.0006 & 0.0007 & 0.0005 & & & \\ & (0.000009) & (0.000009) & (0.000009) & & & \\ \text { Non-Repeal } & 0.0557 & 0.0430 & 0.0447 & 0.0127 & -0.0018 & 0.0110 \\ & (0.0005) & (0.0004) & (0.0004) & (0.0007) & (0.0006) & (0.0007)\end{array}$

Beer Tax in cents $(\$ 1999)$

$\begin{array}{lcccccc}\text { Repeal } & 17.3 & 26.8 & 52.1 & & & \\ & (0.1) & (0.2) & (0.1) & & & \\ \text { Non-Repeal } & 73.4 & 67.9 & 58.2 & 15.0 & 35.1 & 50.1 \\ & (0.4) & (0.3) & (0.3) & (0.5) & (0.5) & (0.4)\end{array}$

Cigarette Tax in cents (\$1999)

$\begin{array}{lcccccc}\text { Repeal } & 23.4 & 40.8 & 49.8 & & & \\ & (0.1) & (0.1) & (0.1) & 16.0 & 4.7 & 20.7 \\ \text { Non-Repeal } & 26.4 & 27.8 & 32.1 & (0.2) & (0.2) & (0.2)\end{array}$

Cigarette Price in cents (\$1999)

$\begin{array}{lcccccc}\text { Repeal } & 168.1 & 218.6 & 231.9 & & & \\ & (0.1) & (0.2) & (0.1) & 23.9 & 8.5 & 32.5 \\ \text { Non-Repeal } & 163.3 & 189.9 & 194.6 & (0.3) & (0.3) & (0.2)\end{array}$

State Income Per Capita (\$1999)

\begin{tabular}{lcccccc} 
Repeal & 26,231 & 28,105 & 27,258 & & & \\
& $(14)$ & $(13)$ & $(16)$ & 308 & -698 & -390 \\
Non-Repeal & 22,641 & 24,206 & 24,057 & $(31)$ & $(31)$ & $(31)$ \\
\hline
\end{tabular}

The data in this table are drawn from multiple data sources. See text for additional details.

Standard errors are in parenthesis. 
Variable

Repeal*D_7072

Repeal*D_7476

Demographic and Time-Varying State Controls?

State Fixed Effects?

Survey Year Fixed Effects?

Cohort Fixed Effects?

F-test on excluded

instruments ( $p$-value)
(1)

(2)

$-3.51$

$-1.89$

$(0.81)$

(1.00)

$-0.27$

1.59

(1.49)

(1.33)

No

Yes

Yes $\quad$ Yes

Yes $\quad$ Yes

Yes $\quad$ Yes

$16.2 \quad 8.1$

$(0.000) \quad(0.001)$

Standard errors allow for arbitrary clustering within a state.

Regressions are weighted using MTF sampling weights.

Data from multiple waves of Monitoring the Future. See text for additional details. 
Table 6. Estimates of Effect of Birth Rate on Subsequent Adolescent Substance Use

\begin{tabular}{|c|c|c|c|c|c|}
\hline & $\underline{\text { Smoke }}$ & $\underline{\text { Drink }}$ & Marijuana & $\begin{array}{c}\text { Any } \\
\text { Illicit Drug }\end{array}$ & $\begin{array}{l}\text { Any Illicit Drug } \\
\text { Except Marijuana }\end{array}$ \\
\hline \multicolumn{6}{|l|}{ Ever Use? } \\
\hline OLS & $\begin{array}{c}0.001 \\
(0.001)\end{array}$ & $\begin{array}{l}-0.0001 \\
(0.001)\end{array}$ & $\begin{array}{c}0.001 \\
(0.002)\end{array}$ & $\begin{array}{c}0.001 \\
(0.002)\end{array}$ & $\begin{array}{c}0.002 \\
(0.001)\end{array}$ \\
\hline TSLS & $\begin{array}{c}0.004 \\
(0.007)\end{array}$ & $\begin{array}{l}-0.002 \\
(0.003)\end{array}$ & $\begin{array}{c}0.011 \\
(0.009)\end{array}$ & $\begin{array}{c}0.009 \\
(0.008)\end{array}$ & $\begin{array}{c}0.011 \\
(0.006)\end{array}$ \\
\hline \multicolumn{6}{|l|}{ Use in Last Month? } \\
\hline OLS & $\begin{array}{c}0.002 \\
(0.001)\end{array}$ & $\begin{array}{c}0.001 \\
(0.001)\end{array}$ & $\begin{array}{l}0.0001 \\
(0.001)\end{array}$ & $\begin{array}{l}0.0004 \\
(0.001)\end{array}$ & $\begin{array}{c}0.002 \\
(0.001)\end{array}$ \\
\hline TSLS & $\begin{array}{c}0.009 \\
(0.006)\end{array}$ & $\begin{array}{c}0.008 \\
(0.006)\end{array}$ & $\begin{array}{c}0.006 \\
(0.004)\end{array}$ & $\begin{array}{c}0.009 \\
(0.005)\end{array}$ & $\begin{array}{c}0.011 \\
(0.003)\end{array}$ \\
\hline
\end{tabular}

The table shows the effect of the birth rate on use where the birth rate is the number of live births per thousand women of childbearing age.

All regressions contain demographic and time-varying state controls as well as state, survey year, and cohort fixed effects.

Regressions are weighted using MTF sampling weights.

Standard errors allow for arbitrary clustering by state. 
Table 7. Abortion Ratio, Early Legalization, and Adolescent Substance Use

A. Effect of the State of Residence Abortion Ratio (Divided by 1000) on Use Within the Past Month

\begin{tabular}{cccccc} 
Smoke & $\underline{\text { Drink }}$ & $\underline{\text { Marijuana }}$ & $\begin{array}{c}\text { Any } \\
\text { Illicit Drug }\end{array}$ & $\begin{array}{c}\text { Any Illicit Drug } \\
\text { Except Marijuana }\end{array}$ \\
OLS & -0.002 & -0.006 & -0.002 & -0.013 & -0.111 \\
& $(0.053)$ & $(0.068)$ & $(0.039)$ & $(0.038)$ & $(0.048)$ \\
TSLS & -0.106 & -0.174 & -0.065 & -0.128 & -0.189 \\
& $(0.080)$ & $(0.095)$ & $(0.070)$ & $(0.078)$ & $(0.062)$ \\
\hline
\end{tabular}

B. First Stage Results of the Effect of Early Legalization on the State of Residence Abortion Ratio

Repeal*D_7072

Repeal*D_7476

Demographic and Time-Varying State Controls?

State Fixed Effects?

Survey Year Fixed Effects?

Cohort Fixed Effects?

F-test on excluded

instruments ( $p$-value)
(1)

(2)

168.6

220.9

(19.2)

150.4

263.0

Yes

No

Yes

Yes

Yes

Yes

Yes

Yes

39.7

121.6

$(0.000)$

(0.000)

The Abortion Ratio is the number of abortions by women from a state per the number of live births to women from that state. The OLS and TSLS results in the Panel A use the abortion ratio divided by 1000 for ease of interpretation.

All regressions contain demographic and time-varying state controls as well as state, survey year, and cohort fixed effects. Standard errors allow for arbitrary clustering by state. Regressions are weighted using MTF sampling weights. 
Figure 1. Fraction of 12th Graders Who Used a Controlled Substance in Past Month
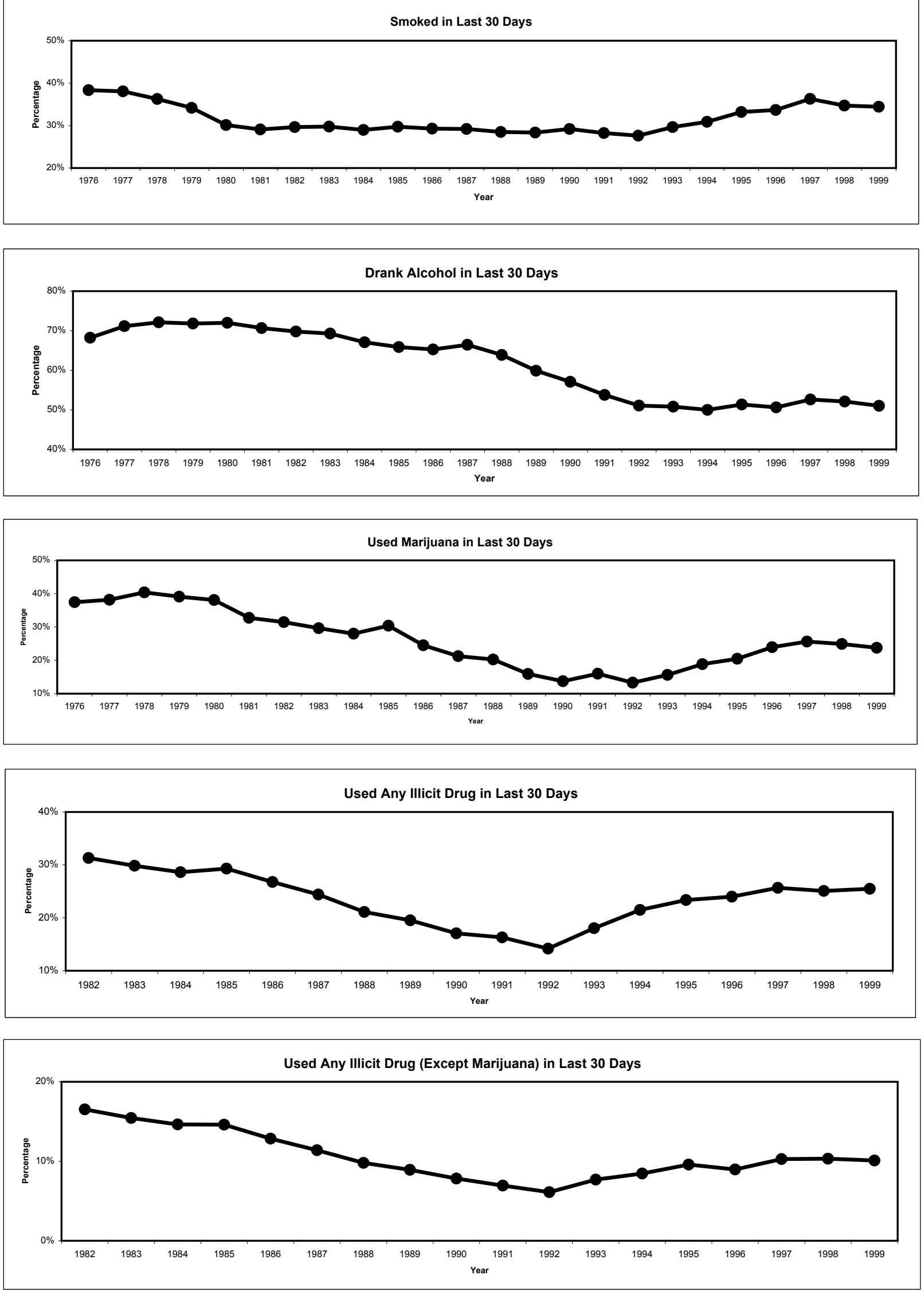